\title{
Parables of Un-freedom: Novels about the Spanish Inquisition in post-1956 People's Poland ${ }^{1}$
}

Można opowiadać miliony anegdot o tym, w jaki sposób obchodzono cenzurę. ${ }^{2}$

[We could tell millions of tales about evading censorship.]

The use of historical events and writings from the medieval and classical pasts to form the basis of new fictions about contemporary society is a phenomenon noted by Annabel Patterson in the Introduction to her revised edition of Censorship and Interpretation (1991). Mid-sixteenth-century English writers' rediscovery of 'a classical system of rhetorical ingenuity', an 'Aesopian language' became the 'medium of a quiet but sustained critique of their government.' In many respects this was a recurrent feature, one that could and did occur within all repressive political systems from the ancient world through Tsarist Russia, where the term 'Aesopian language' acquired specific currency, ${ }^{4}$ to the countries of Eastern Europe that found themselves under Soviet domination after the Second World War. The Aesopian strategy of ' $[\mathrm{t}] \mathrm{elling}$ a story which appears to have nothing to do with present political concerns and leaving it to the readers (viewers, theatre-goers) to make connections that are apparently hidden from the censor' ${ }^{5}$ often informed literary forays into the distant past. Tropes of heresy and resistance to tyrannical rule provided abundant analogies

* Dr, e-mail: John.Bates@glasgow.ac.uk; School of Modern Languages and Cultures; University of Glasgow, G12 8RS, Scotland, Great Britain.

${ }^{1}$ This publication is one of the outcomes of the research project "Examining Patterns of Representation in Literary Discourses" (OPVK CZ.1.07/2.3.00/20.0125), which has been jointly financed by the European Social Fund and the State Budget of the Czech Republic.

${ }^{2}$ W. Władyka, “Zabijanie słów. O cenzurze w PRL”, Biuletyn Instytutu Pamięci Narodowej, 2004, issue 2, p. 7.

${ }^{3}$ A. Patterson, Censorship and Interpretation. The Conditions of Writing and Reading in Early Modern England, The University of Wisconsin Press, Madison, Wisconsin 1991 [1984], p. 19.

${ }^{4}$ See Robert Justin Goldstein's entry on 'Aesopian Writing', in: Censorship. A World Encyclopedia, D. Jones (ed.), Fitzroy Dearborn Press, London-Chicago 2001, pp. 16-17.

${ }^{5}$ Ibid., p. 16. 
with more contemporary forms of dissent. The style and degree of suppression of unorthodox beliefs and behaviour might change yet the principles behind it remained the same.

Traditional approaches stressing the duping of the censor have increasingly given way to more nuanced analyses of the relationship between the author and his/her various readers (who included censors). In 1973, the emigre writer Witold Wirpsza provided an analysis of a then-recent article in the Workers' Party's monthly Nowe Drogi, which led him to use the term 'Party Chinese ('chińczyzna partyjna')' as a way to define the article's deliberately oblique response to young writers' calls for the right to depict contemporary reality in a realistic fashion. ${ }^{6}$ Describing these strategies somewhat provocatively as manifestations of 'Aesopian language' inscribed the leadership into practices traditionally associated with those subject to the operations of, rather than being the agents exercising, political power. ${ }^{7}$ Wirpsza's broader, if unstated, implication that meaning is negotiated between the discrete players - be they representatives of political authority (politicians, censors), receivers (critics, readerships) and senders (writers, critics) - allows for a more subtle view of the (literary) communication process than that permitted by simple binary oppositions. While the authorities' or censors' aspirations to control meaning, or conversely to ascribe liberal tendencies to their activities, cannot be denied, it establishes them as one of the main agents in the process. Moreover, it cannot be gainsaid that censors were aware of subversive readings, hence the existence of potentially dissenting texts within official circulation suggests they were conditionally accepted.

The extent to which such works were tolerated, and the reasons for this, is one of the larger, possibly ultimately unanswerable questions of the present article. Aesopian writing had been a significant feature of vernacular Polish literature since the late Middle Ages but the experience of foreign occupation in the years 1795-1918 caused domestic Polish literature to elaborate the strategy to a much greater degree. Within an increasing literate and better culturally educated postwar Poland, the number of readers, including official censors, capable of grasp-

${ }^{6}$ PZPR KC WK AAN LVI - 1333 (1973) Wydział Kultury KC PZPR 1973. Document 27 of this file is a six-page resume of Wirpsza's piece 'Cenzor jest zawsze morderca - Beznadziejna sytuacja intelektualistów polskich', which appeared in Deutsche Zeitung - Christ und Welt, 15 June 1973, pp. 4-5.

${ }^{7}$ This suggests a somewhat more complex communicative situation than that suggested in the most recent Anglophone take on Aesopian language: "in this shift from an "official" to an Aesopic discourse, there is thus a double alteration of reality at work: while the powers-that-be manipulate reality to serve their own ends and to obstruct it from being seen, understood and potentially changed, critical thinkers "veil" it in Aesopic devices to expose the second alteration.' G. Reifarth and P. Morrissey, "Aesopic Voices: A Foreword", in: Aesopic Voices. Reframing Truth through Concealed Ways of Presentation in the 20 $0^{\text {th }}$ and $21^{\text {st }}$ Centuries, Cambridge Scholars Publishing, Newcastle upon Tyne 2011, pp. 1-12 (p. 3). 
ing the principles of Aesopian language expanded rapidly. Furthermore, as if in recognition of the fact, by the 1970s university lecturers were providing crash training courses in the history of Polish literature for censorship employees. ${ }^{8}$ To some extent grasping the principles of Aesopian language could lead to its being seen everywhere and certainly a key part of the literary censor's activity lay in testing this assumption to the point of absurdity. The readability of such texts, their potential subversiveness may be said then to be further obscured by the censor's actions. After 1956 particularly, relatively few texts were banned unconditionally and those works perceived as Aesopian could play the role of a social safety-valve, tolerated as a relatively uncostly and politically expedient form of sanctioned dissent.

In this article, 'Aesopian writing' is related closely to the genre of the historical novel. Jerome De Groot, albeit without reference to Aesopian strategies, has emphasized the genre's particular suitability as a vehicle for subversion: 'A historical novel is always a slightly more inflected form than most other types of fiction, ${ }^{, 9}$ one which also tends to work in collusion with its audience. ${ }^{10}$ He goes on to note the intrinsically subversive nature of certain of its manifestations, specifically where such works set out to challenge history. In such cases the role of the historical novel as a disruptive genre comes to the fore, representing 'a series of interventions which have sought to destabilise cultural hegemonies and challenge normalities. ${ }^{11}$ If we see such 'cultural hegemonies' and 'normalities' with their concomitant narratives as officially generated in People's Poland, the extent to which post-war Polish historical fictions may be seen to fulfil these terms merits some attention.

The ultimate focus of this chapter accordingly falls on the composition and critical reception of three communist-era Polish historical novels portraying the Spanish Inquisition of the late fifteenth century. These works - Jerzy Andrzejewski's Ciemności kryja ziemię (And Darkness Covered the Earth, aka The Inquisitors, 1957), Julian Stryjkowski's Przybysz z Narbony (The Stranger from Narbonne, 1978) and Józef Cepik's Torquemada (1986) - enable a closer examination of the functions of the historical novel with prominent Inquisition tropes within communist-era discourse. Patterson stresses the 'importance of an exact chronology in determining what any given text was likely to mean to its audience at the time of its appearance, ${ }^{12}$ which informs my approach here. The dates of publication and the works' respective socio-political and cultural contexts are

\footnotetext{
${ }^{8}$ Comment by Professor Jakub Lichański (September 1997). See also P. Misior, Ja, Tomasz Strzyżewski. O cenzurze i cenzorach, Léon Bonnet \& Co., Krakow 1997, pp. 60-61.

${ }^{9}$ J. de Groot, The Historical Novel, Routledge, London and New York 2010, p. 4.

${ }^{10}$ Ibid., p. 6.

${ }^{11}$ Ibid., p. 139.

${ }^{12}$ A. Patterson, op. cit., p. 55.
} 
crucial to the analysis of their potential use by readers. Invariably the political, rather than aesthetic, dimensions of these works and their reception will take precedence in the analysis. At the outset, however, this chapter seeks to locate these works within the artistic practices and cultural-political discourse of the period with an emphasis on the institutional constraints that find expression in the censors' information about the subterfuges to which authors resorted in their attempts to deceive.

\section{Institutional Censorship and Literary Allusion in Post-War Poland}

The principle of limiting the political resonance of historical works broadly informed their interpretation by censors throughout the post-war period. In the immediate aftermath of World War Two the use of such strategies was particularly identified with Catholic authors and journalists. The ambiguities which the practices generated caused censors initially to hesitate when excising these references during the period of notional multi-party democracy (1945-47), as Director Kowalczyk's briefing at the second national conference of censorship offices in January 1946 indicates:

The use of analogies. Writing about something that doesn't concern us, or about someone else: the Hungarian elections or the victory of the Catholics in France, but in such a way as to induce the suggestion that it could apply to our area. [...] analogy is the second method employed by Catholic columnists. [...] And finally a new genre, equally effective, which is a style based on specific allegories, characterised by their being taken from the Gospels, often with references to certain biblical stories...

[Posługiwani[e] się analogią. Pisze się niby o czymś co nas nie dotyczy, o kimś co jest pisane o kimś innym: o wyborach na Węgrzech i zwycięstwie katolików we Francji i tak się pisze, że się wzbudza sugestię, którą można zastosować do naszego terenu. [...] posługiwanie się analogią należy do drugiego środka, którym się publicystyka katolicka posługuje [...] Wreszcie nowy rodzaj, rodzaj również skuteczny, to jest t.zw. styl zbudowany na pewnych alegoriach, który się charakteryzuje tym, że jest brany z ewangelii, nieraz są odnośniki do pewnych biblijnych historii... $]^{13}$

After 1947, with the demise of the independent political opposition, censors proved less squeamish. Analogies between the persecution of the early Christians under Rome and the situation of Catholics in the Marxist regime were

\footnotetext{
${ }^{13}$ GUKP, 421 tom II, Odprawy krajowe 1946 r., pp. 40-41.
} 
rigorously controlled with plays that offended on this count being removed from the repertoire. ${ }^{14}$

These restrictions came to apply also to introductions to literary works (and critics' reviews). Mention of a work's broader political relevance, and especially its contemporary resonance for readers, led to the removal of Zbigniew Herbert's play The Philosopher's Cave, which examined Socrates' final imprisonment, from his collection Dramaty (Dramas) in 1967. According to censorship officials, 'these "events" are only a backdrop for the author's own reflections on philosophical matters - life, death - but above all on political issues such as power and the rule of law, etc. The main stratum of the play is the drama of a wise, outstanding individual entangled in the eternal conflict with power, which is mindless and tyrannical. [Ale owe "wydarzenia" są tylko kanwą, na której autor snuje rozważania na tematy filozoficzne - życia, śmierci - i przede wszystkim - polityczne - jak zagadnienia władzy, praworządności itp. Główną warstwą sztuki jest dramat człowieka mądrego, wybitnego uwikłanego w odwieczny konflikt z władzą bezmyślną, tyrańską. $]^{15}$ Here the intractable problem from the censor's perspective was the author's own indications as to how the work should be read, ${ }^{16}$ which defied censorship working practices.

The formalisation of censorship strategies towards suspect texts achieved its definitive formulation in a number of documents from the late 1970s and early 1980s. The index for the January 1980 edition of the censor's Monthly Instructional Materials includes as item 10 'The Interpretation of Texts,' clarifying the censorship office's concern as follows: 'The proper interpretation of texts whose social or political meaning is deliberately concealed by authors with the aid of allegories or other stylistic and linguistic devices. ${ }^{17}$ The related material given as an example of such concealment is a poem by M. Kraiński in the Gdansk student monthly, Punkt. Although ostensibly dealing with the French Revolution, the poem's implications could be extended to the present Polish political regime. The team of censors discussing the poem conclude that, 'in spite of the hermeticity of the language, the author's intention is clear and most of those

\footnotetext{
${ }^{14}$ Specific materials relating to this matter can be found in the state archives in Poznan under: Zespół Wojewódzki Urząd Kontroli Prasy, Publikacji i Widowisk w Poznaniu, 249 "Recenzje oraz ingerencje dotyczące widowisk i sztuk teatralnych 1945-1954".

${ }^{15}$ Przeglądy ingerencji i przeoczeń w publikacjach periodycznych, nieperiodycznych, drukach ulotnych I, II, III kwartał 1967 r., pp. 140-141.

16 'Where it touches upon the question of power the play is full of allusions to the present day and would be interpreted in that way, especially since the author in his prologue emphasizes the allusive nature of the work and guides the reader's attention in that direction. [Sztuka we fragmentach dotyczących problemu władzy, pełna aluzji do współczesności i byłaby odczytywana w związku ze współczesnością, zwłaszcza, że autor już w prologu podkreśla jej aluzyjność i zwraca w tym kierunku uwagę odbiorcy.]' Ibid., p. 141.

${ }^{17}$ GUKP, 1538, Informacje instruktażowe miesięczne 1980, pp. 48-49.
} 
participating in the discussion interpreted the poem as an attempt to show that revolutionary power becomes distorted and ends up on the "rubbish tip" (Wydaje się, że intencja autora mimo hermetyczności języka - jest czytelna i większość uczestniczących w dyskusji ją odczytała, jako próbę wykazania, że władza rewolucyjna ulega deformacjom, kończy na "śmietniku".)' Moreover, neither the difficult nature of the text nor its niche audience provide an alibi automatically justifying its 'release' into the public domain: the undesirability of the text's message remains the paramount concern. This seemingly authoritative position is then qualified significantly by an admission of deviations from the norm, albeit in special circumstances: 'It is worth noting that sometimes consciously - on exceptional grounds and for precisely defined reasons - a text that evokes the censor's reservations is released. This is done consciously, sometimes even deliberately, but with the knowledge and agreement of the Main Office's directors. [Warto zauważyć, że czasem świadomie - na zasadzie wyjątku, ze względu na ściślej określone powody - zwalniany jest tekst budzący zastrzeżenia. Jest to jednak czynione świadomie, czasem nawet celowo, ale za wiedzą i zgodą kierownictwa Urzędu.] $]^{18}$

The key term in the censorship team's assessment of Kraiński's piece is 'intention'. Throughout the whole post-war period, the censorship office tended to presume writers guilty of a desire to subvert the system. Intentionality has subsequently assumed a crucial position in Polish scholars' thinking about Aesopian texts, ${ }^{19}$ posing the question of whether it is possible to distinguish what is 'purely artistic creation' from 'a strategy designed to combat censorship'. ${ }^{20}$ The ontological status of the artistic utterance is here at stake with the consequence that texts may be identified as Aesopian, where their authors possessed no such intention. The audience response may therefore constitute a profoundly reductive reading of the work, marginalising elements that do not conform to the expected political subtext. ${ }^{21}$

${ }^{18}$ Ibid., p. 49.

${ }^{19}$ See J. Smulski, „Jak niewyrażalne staje się wyrażalne? O języku ezopowym w prozie polskiej lat pięćdziesiątych", in: Literatura wobec niewyrażalnego, W. Bolecki and E. Kuźma (eds.), PAN, Warsaw 1998, pp. 145-164; and Kamila Budrowska's overview of the debates in Literatura i pisarze wobec cenzury PRL 1948-1958, Wydawnictwo Uniwersytetu w Białymstoku, Białystok 2009, pp. 240-246.

${ }^{20}$ K. Budrowska, op. cit., p. 241.

${ }^{21}$ Bogusław Sulikowski has used Polish audience responses to Miloš Forman's film version of One Flew over the Cuckoo's Nest to demonstrate precisely this point. He argues that the key idea for the Polish audience was that of the 'institution as totalitarian state', which completely overshadowed both the psychiatric elements as well as the psychological motivation of those who upheld the ward's repressive regime. "Ten przeklety jezyk ezopowy...”, in: Piśmiennictwo - systemy kontroli - obiegi alternatywne, tom II, J. Kostecki and A. Brodzka (eds.), Biblioteka Narodowa, Warsaw 1992, pp. 265-284 (pp. 280-81). 
Annabel Patterson's concept of 'functional ambiguity' is helpful here: as she notes, 'authors who build ambiguity into their works have no control over what happens to them later.'22 It neatly side-steps the theoretical impasse into which these deliberations can rapidly lead and liberates us from the need to ascribe a work's meaning to either the author or his/her audience. The focus of the present article then falls upon the ways in which subversive meanings may be activated both by the text's formulations and the audience's reception. For my purposes here the audience reception is provided by contemporary reviews of the three works.

\section{Historical Fiction, "Heretical" Thinkers and the Regime}

Truly effective censorship nonetheless required positive promotion of the regime's desired models. This was most visible under Socialist Realism (1949-55), when a marked official preference for literary works dealing with the rapid industrialization and socio-political transformation of Polish society marginalized historical works, except insofar as they could demonstrate the historical rightness of the Party's political line. The major literary cycle of this period, Antoni Gołubiew's series of novels about Bolesław Chrobry, the first king of Poland (992-1026), challenged official mores and was accordingly systematically denigrated in censorship reports. ${ }^{23}$ Here the correct interpretation of the past, particularly to explain the creation of People's Poland as the ultimate development of Polish statehood with special emphasis placed on justifying the new post-war borders, informed censorship critiques of Gołubiew's work. In the absence of broader public support the communists were keen to establish a cultural and intellectual canon, which advanced those writers and thinkers they regarded as progressive. ${ }^{24}$ The Stalinist regime therefore expended greater efforts on translating and disseminating the works of renowned Polish radicals from the late medieval period onwards.

One dimension of this activity was a communist state-sponsored international project in Hussite studies, ${ }^{25}$ to which Polish scholars made a substantial

\footnotetext{
${ }^{22}$ A. Patterson, op. cit., p. 18.

${ }^{23}$ Its non-Marxist exposition of Polish history was rigorously criticized in the censors' reviews. See my "Cenzura wobec problemu niemieckiego w literaturze", in: Presja i ekspresja: Zjazd Szczecinski i Socrealizm, D. Dąbrowska and P. Michałowski (eds.), Wydawnictwo Naukowe Uniwersytetu Szczecinskiego, Szczecin 2002, pp. 79-92.

${ }^{24}$ Zbigniew Romek's discussion of the debate surrounding the definition of 'progressive' among Polish historians from the later 1940s indicates its problematic status. Cenzura a nauka historyczna w Polsce 1944-1970, Wydawnictwo Neriton, Warsaw 2010, pp. 165-172.

${ }^{25}$ See Mezinárodní ohlas Husitství, J. Maček (ed.), Nakl. Československé akademie věd, Prague 1958.
} 
contribution, the effect of which appears to have been grossly to exaggerate the scale of the phenomenon in late medieval Poland. ${ }^{26}$ The popularization of the work of the Polish Jacobin Hugo Kołłąaj (1755-1810) and the publication of the collected works of Andrzej Frycz Modrzewski (1503-72) in a vernacular translation, which were major achievements for Polish publishers in this period, constituted a central plank of this policy. Modrzewski also received literary treatment in Anna Kowalska's Wójt Wolborski (1954, and its second part Ad Astrea, published in 1956), the discussion of which in censorship files demonstrates the problems of the historical novel as a vehicle for transmitting ideologically desired content. Invariably the complexity of the period's portrayal impeded the work's readability for a mass audience. ${ }^{27}$ This could sometimes lead to a work's not being published, ${ }^{28}$ since it would fail to achieve its ideological purpose, but the need for a broadly politically acceptable version of the great Renaissance thinker's life seems to have outweighed these drawbacks. ${ }^{29}$

Even during the Stalinist era, as Jerzy Smulski has argued, the existence of Aesopian historical works may be detected. ${ }^{30}$ Two prominent examples he analyses are Hanna Malewska's short stories addressing the situation of intellectuals in the Tudor period (Sir Thomas More odmawia, 1951, and Koniec Cramnera, 1956) and Bogusław Sujkowski's novel Liście koka (Leaves of Cocoa, 1954), set during the Spanish conquest of sixteenth-century Peru, which will be considered at greater length below. These works about tyranny in a distant time and place granted censors and the political authorities an alibi should they fail to appreciate possible subversive readings: in other words functional ambiguity provided reasonable doubt.

After 1956, this repertoire of strategies acquired greater sophistication with the foregrounding of the Catholic Church - invariably seen as a force of reaction and hence at the opposite end of the political spectrum from the Communist Party - especially in its most censorious form (the medieval Inquisition), as a parallel to the repressive apparatus of the Stalinist regime. Leszek Kołakowski's numerous

${ }^{26}$ P. Kras, Husyci w piętnastowiecznej Polsce, Towarzystwo Naukowe KUL, Lublin 1998 , pp. $26-27$.

${ }^{27}$ The excessive degree of historical knowledge which the author seemed to require of the reader made it unintelligible for the average reader in the view of the first censor. GUKP 386, PIW 1954, p. 21.

${ }^{28}$ As the second report proposed: ibid., pp. 23-25. This censor also noted the author's over-deference to the impact of Western influences on Frycz's thought.

29 The final, post-publication review reiterated the earlier criticisms while acknowledging the novel's ideologically correct interpretation of class relations between the lesser nobility and magnates: 'ukazano w niej słusznie obóz postępu walczący bohatersko przeciwko szlachecko-magnackiej oligarchii [the progressive camp is shown rightly in its heroic struggle against the magnate oligarchy].' Ibid., p. 29.

30 “Jak niewyrażalne staje się wyrażalne?", pp. 147-152. 
essays on a reformed state socialism during the 'Thaw' period, and particularly his highly influential 'Kapłan i błazen (The Priest and Jester)', ${ }^{31}$ examined contemporary Marxism precisely in terms of its 'theological' outlook, that is the justification of present human sacrifice in expectation of future goods (the utopian social order). ${ }^{32}$ The conclusions of Zbigniew Herbert's essays on the suppression of the Templar Order and the thirteenth-century crusade against the Albigensians in his volume Barbarzyńca w ogrodzie (Barbarian in the Garden, 1962) suggested the more general contemporary relevance of specific historical examples. As he states at the end of 'Obrona Templariuszy (Defence of the Templars)': 'The methods used in the struggle against the Templars have entered the repertoire of power. For that reason we cannot leave this distant affair to the archivists' pale fingers. [Metody użyte we walce z Templariuszami weszły do repertuaru władzy. Dlatego nie możemy tej odległej afery pozostawić bladym palcom archiwistów.] ${ }^{33}$ Notably there is no geographical reference here to People's Poland, let alone to any of the communist states, which prompts several more general reflections about the use of such tropes.

Apart from their specificity, and the individual status of the writer employing them, ${ }^{34}$ the format and place of publication also played a part in determining their acceptability. ${ }^{35}$ The limits that the censorship office imposed on the use of the metaphor of the Catholic Church in relation to the Party, even at a relatively liberal juncture, can be seen in a report dated 10 February 1958. The article 'Życie Galilei [Life of Galileo]' was confiscated from the twentyfourth number of the magazine Nowe Sygnaty because of its 'very transparent allusions to the current situation in the Party [skonfiskowano artykuł o bardzo przejrzystych aluzjach do obecnej sytuacji w partii]'. ${ }^{36}$ The discussion between Cardinal Barberini, later Pope Urban VIII, and Galileo, takes up the subject of the free exchange of ideas.

${ }^{31}$ Its full Polish title is "Rozważania o teologicznym dziedzictwie współczesnego myślenia (Reflections on the Theological Legacy of Contemporary Thought)." The English translation can be found in Towards a Marxist Humanism. Essays on the Left Today by Leszek Kolakowski, trans. J. Zielonko Peel, Grove Press Inc., New York 1968, pp. 9-37.

32 'In its modernized version it (theodicy - JB) concerns the rationalism of history, the question whether the individual's misfortunes and suffering have meaning and justification within a universal historical rationality." "The Priest and the Jester", p. 12.

33 "Obrona Templariuszy (Defence of the Templars)", Barbarzyńca w ogrodzie, Czytelnik, Warsaw 1964, p. 215.

${ }^{34}$ Kołakowski may have enjoyed a certain official credit due to his work criticizing Catholicism in the early 1950 s.

35 "Kapłan i błazen" was first published in the literary monthly Twórczość, whose profile became increasingly avantgarde.

${ }^{36}$ GUKP 656, "Przeglądy ingerencji - przeglądy przeoczeń 1958-1959 (159/1)”, Przegląd ingerencji $\mathrm{Nr} 2 / 58$, p. 11. 
Barberini: We understand the need and necessity of a broad creative discussion but only up to the moment when an encyclical is published. Then the discussion should be broken off. That, my son, is and must be the Church's position.

Galileo: But do you not consider this, Your Eminence, to be a position harmful to the Church itself? Certain previous experiences would seem to indicate that it is...

Barberini: I know what you mean but cannot agree with you. Have no doubt, Galileo, that I appreciate the danger of the Inquisition, which I condemn like you and of which I am ashamed as a Christian. But discipline and obedience in God's Church do not have to be synonymous with the reign of the Inquisition, which - I believe - we will finally manage to rein in and suppress. [...]. The greatest good is Church unity but this we shall definitely not preserve if we agree to endless discussions of matters upon which the Holy Office has alredy pronounced its judgment based on Holy Scripture and Christ's teachings - obviously freely adapted to real life and brought closer to the common people.

[Barberini: Rozumiemy dobrze potrzebę i konieczność szerokiej, twórczej dyskusji, ale tylko do czasu ogłoszenia encykliki. Potem duskusja powinna być przerwana. Takie jest, mój synu, i takie musi być stanowisko Kościoła.

Galileo: Czy nie sądzi pan, Eminencjo, że jest to stanowisko szkodliwe przede wszystkim dla Kościoła samego? Pewne doświadczenia zdawałyby się może na to wskazywać...

Barberini: Wiem, co pan ma na myśli, ale nie mogę się z panem zgodzić. Nie wątpi pan, Galileuszu, że doceniam niebezpieczeństwo Inkwizycji, którą potępiam jak i pan i której wstydzę się jako chrześcijanin. Ale karność i posłuszeństwo w Kościele Bożym nie muszą być jednoznaczne z panowaniem Inkwizycji, którą - jak mniemam zdołamy wreszcie okiełzać i ukrócić. [...] Dobrem najwyższym jest jedność Kościoła a tej nie ocalimy na pewno, jeśli zgodzimy się na roztrząsanie w nieskończoność zagadnień o których Święte Officium wydało już swój wyrok w oparciu o Pismo Święte i naukę Chrystusową - oczywiście twórczo zastosowaną do życia i zbliżoną do gminu. $]^{37}$

The implicit connection between the Holy Office and the Party leadership, apart from the similarly irrevocable nature of their utterances, is suggested by the use of contemporary party phraseology, a usage which is evidently anachronistic in the sixteenth-century context. This deliberate use of anachronism fulfils Michael Riffaterre's definition of 'ungrammaticality' in respect of forcing the reader to shift from the mimetic to the metaphorical plane of interpretation. ${ }^{38}$ (In many

\footnotetext{
${ }^{37}$ Ibid., pp. 11-12.

38 'To discover the significance at last, the reader must surmount the mimesis hurdle [...] The reader's acceptance of the mimesis sets up the grammar as the background from which the ungrammaticalities will thrust themselves forward as stumbling blocks, to be understood eventually on a second level.' M. Riffaterre, Semiotics of Poetry, Methuen and Co. Ltd, London 1978, p. 6.
} 
respects, Polish readers - as I argue below - were constitutionally attuned to receiving such ungrammaticalities.) The specific phrase that helps to trigger contemporary associations is 'potrzeba (...) szerokiej, twórczej dyskusji [need for (...) a wide-ranging, creative discussion],' a staple cliche of Thaw-era party discourse. The exact contemporary counterpart of the Inquisition is not entirely clear, although the socially and intellectually repressive functions it performs suggest both the secret police and the censorship apparatus, whose collaboration proved crucial to suppression of the political opposition in the late 1940s. Barberini's counterpart may be the enlightened members of the party leadership who sought to engage with intellectuals in a more open manner, appealing to the latter's sense of responsibility for current developments. ${ }^{39}$ The particular problem appears to be two-fold: firstly, the place of publication (periodicals tended to have a larger production run than standard literary works) and secondly the nature of the work itself, which consists entirely of a set of exchanges without any mediating context - and hence fails to offer any plausible deniability in terms of variant readings. Its 'functional ambiguity' is thereby severely impaired.

By the end of the 1960s, the criteria applied to works passed by the censorship office in the 'Thaw' period underwent major revisions. The censorship office's earlier approach seemed increasingly too liberal, as the Head of the Department of Non-Periodical Publications made clear in a report from January 1969:

All books that are being reissued, and which were inspected in the years 1956-1960, are also being subjected to renewed inspection. This is due to the fact that current criteria and demands differ from the criteria that applied then. Practice shows that in many of these reissued items we have had to carry out political interventions.

[Również ponownej kontroli poddawane są wszystkie książki wznawiane, a które były kontrolowane w latach 1956-1960. Jest to spowodowane okolicznością, że kryteria i wymogi obecne rożnią się od kryteriów obowiązujących w tamtych latach. Praktyka wskazuje, że w wielu wznawianych pozycjach, musieliśmy dokonywać politycznych ingerencji. $]^{40}$

This document indicates a significant policy shift. The literature of the Thaw period was now deemed politically suspect in a far more explicit manner and the fact of its previous publication could not be construed as providing a precedent for republication.

${ }^{39}$ The Hungarian crisis of November 1956 is a case in point where journalists, in the absence of a fully functioning censorship, were effectively asked to self-censor or exercise self-restraint in their reporting.

${ }^{40}$ PZPR KC w Warszawie, Wydział Kultury II, 1354 AAN, 859, 1967-1969, “Sprawozdanie z działalności w 1968 r.”, p. 3. 
Dissatisfaction with Aesopian strategies, which is part of the problem here, was also expressed by writers of the younger generation who directly criticized the techniques adopted by Andrzejewski and Herbert among others. Its classic exposition came in Adam Zagajewski and Julian Kornhauser's Świat nieprzedstawiony (Unrepresented World, 1974) but their general case in favour of 'mówienie wprost (straight-talking)' receives confirmation from a representative voice in the previously cited Wirpsza article:

Our language is a system of analogies and allegories, an abstract language which excludes the description of the conditions of our existence. And precisely the fact that this type of culture remains silent about the fundamental, basic problems, means that as a result suspicion falls on honest people. If a culture excludes from its sphere the basic problems, everything becomes suspect.

[Nasz język jest systemem analogii i alegorii, językiem abstrakcyjnym, który wykluczył opisywanie warunków naszej egzystencji. I właśnie fakt, że tego rodzaju kultura przemilcza zasadnicze, podstawowe problemy, sprawia, że w wyniku tego pada podejrzenie na uczciwych ludzi. Jeśli dana kultura wyklucza ze swej sfery podstawowe problemy, wszystko staje się podejrzane. $]^{41}$

Although this idealistic comment typifies a particular historical moment - it predates the rise of the 'second circulation' of underground publication in 1976 which would make its diagnosis largely redundant - it captures the pathology to which the Polish literary culture and readership were prone. On the one hand the speaker suggests the incommensurability of past, often foreign examples to the Polish present day - a perception which applies equally to the nineteenthcentury experience of the partitioning powers' censorship regimes. (Zbigniew Kubikowski, in a posthumously published series of articles on post-war prose, utilized the metaphor of the 'glass wall' to describe this distance between Polish literature and its native audience's historical experience. $)^{42}$ Conversely, the abnormal situation - in which key questions cannot be addressed - encourages inveterate subversive reading strategies irrespective of the author's ('innocent people') or even the text's intentions. The key word in the young poet's critique is 'przemilcza' ('remains silent about'), which evokes related terms like 'niedomówienie' or 'niedopowiedzenie' ('elliptical statement' but more literally 'unsaidness' or 'incomplete utterance') as responses in the face of an ideological censorship which pretended to the status of a 'logocracy', as Arlen Blyum has termed it. ${ }^{43}$ Despite

${ }^{41}$ PZPR KC WK AAN LVI - 1333 (1973) Wydział Kultury KC PZPR 1973. Document 27, p. 3.

42 "Szklany mur", Odra 1983-84.

43 'Its purpose [ideological censorship - JB] was to force people to have the exclusively "correct" ideas about the world, to form the man equipped with the one and only true Weltanschauung. 
the implicit desire for 'straight-talking', the younger generation proved as adept at employing strategies of circumlocution as the older. The remainder of the present chapter will examine the prevalence of these strategies in relation to a number of literary works presenting the same historical 'costume' of the Spanish Inquisition, albeit to different effect and with variant purposes. To what degree and how do the authors articulate the broader issues of Polish experience of oppression? The question is then one of the extent to which these issues are discussed in the public sphere that is not merely the domain of propaganda.

Central to this approach is the focus on the concept of 'silence' ('milczenie'). In his study of Andrzejewski's Ciemności, Jürgen Schreiber approaches the novel ultimately through an examination of its keywords, which help to take his analysis beyond the novel's immediate context and questions of its adequacy in relation to contemporary Polish experience. ${ }^{44}$ A notable and surprising absentee among these keywords - given its prevalence in the novel and applicability to the operating practices of the medieval Inquisition and communist rule alike - is the term 'silence'. Following Wendy Brown, I will problematize use of the term: silence is considered as a 'political value, a means of preserving certain practices and dimensions of existence from regulatory power, from normative violence'. ${ }^{45}$ Likewise the silences of Andrzejewski's and the other novelists' characters - I will argue - do not always constitute acts of absolute subjugation to dominant authority.

\section{'[Every]body expects the Spanish Inquisition...': Three Portrayals of the Inquisition in late Fifteenth-Century Spain}

The use of Iberian and Latin-American historical contexts as models for exploring the Polish socio-political condition in prose can be traced back to at least the late Partitions. In his preface to his 1902 novel Upiory (Phantoms), Walery Przyborowski provided a key to the work, explaining inter alia that medieval Bilbao should be read as Warsaw during the 1863 uprising, that the famous Warsaw

The Soviet state came to be dominated not so much by an ideocracy as by a logocracy - the power of words. [...] what mattered was to write and say the necessary words, to maintain some form of ideological decorum.' A. Blyum, A Self-Administered Poison. The System and Functions of Soviet Censorship, trans. by IP Foote, University Humanities Research Centre, University of Oxford, Legenda Special Lecture Series 5, 2003, p. 10.

44 J. Schreiber, Jerzy Andrzejewskis Roman "Ciemości kryją ziemię" und die Darstellung der spanischen Inquisition in Werken der fiktionalem Literatur, Verlag Otto Sagner, München 1981, pp. 121-159.

${ }^{45}$ W. Brown, "Freedom's Silences", in: Censorship and Silencing. Practices of Cultural Regulation, Robert C. Post (ed.), The Getty Institute for the History of Art and the Humanities, Los Angeles CA 1998, pp. 313-327 (p. 314). 
street Krakowskie Przedmieścia (literally 'Cracow Suburbs') had been recast as Madrid Suburbs, while the hero's name Bona Fide represented a calque of the reallife (Stanisław) Traugutt, the leader of the Polish insurrection. ${ }^{46}$ A more typically covert approach to the use of the Latin-American context emerges from Bogusław Sujkowski's Liście koka (Cocoa Leaves, 1954). Its external form - the unmasking of the evils of Spanish colonization of the Inca empire - caused its first censor, a certain Tomczak, to view it in simplistic Marxist terms:

Its value lies above all in the fact that it acquaints the [Polish] reader with the problem of colonialism in its embryonic form, it unmasks the world of hypocrisy and duplicity of those colonizers, provides a highly accurate attack and condemnation of ownership as injustice and exploitation.

[Wartość jej polega przede wszystkim na tym, iż zapoznaje ona czytelnika z problemem kolonialnym w jego zarodkowej formie, demaskuje świat obłudy i kłamstwa ówczesnych kolonizatorów i ich spadkobierców współczesnych imperialistów, godzi bardzo trafnie i potępia prawo własności, jako prawo krzywdy i wyzysku. $]^{47}$

The ideologically problematic conception of the Inca state, whose very organization was responsible for its collapse, caused Tomczak to qualify his initial praise of the work's 'historical truth'. In that state, 'each individual was controlled by [the state], had no will or power to direct his own fate, since everything was governed by orders from above [każda jednostka była nim kierowana, nie posiadała woli ani mocy pokierowania swym losem, gdyż wszystkim rządził rozkaz z góry]. ${ }^{98}$ The implications of this analysis - its applicability to the communist system - remained unexplored by Tomczak and his superior Lassoń, who granted permission for the book to be typeset in September 1953. A second review, dated February 1954, indicates that these implications were subsequently appreciated and may have delayed the book's eventual appearance. ${ }^{49}$ Certainly

46 The oddity of Przyborowski's practice lies in the fact that he reveals his ingenuity thereby exposing its redundancy in the Austrian context and also, given Russian censors' sensitivity to works published in the other partitions, ensuring that his work will not be published in the most immediately relevant sector.

${ }^{47}$ GUKP 375 (31/35), p. 604.

48 GUKP 375 (31/35), p. 607.

${ }^{49}$ Five months is a considerable delay between the initial censorship report and release of the book. The second censor, noted that 'sieć urzędników państwowych kontroluje i reguluje każdy, najmniejszy odcinek życia poddanych [...] każdy mieszkaniec państwa "Inków" wykonuje swą pracę na rozkaz urzędnika [...] bez rozkazu nie wolno zaczynać siewów ani zbiorów, przenosić się do innej wsi, zmieniać pracę' [a network of state functionaries controls and regulates every little segment of the subjects' lives [...] each inhabitant of the Inca state carries out his work at the functionaries' command [...] without such a command crops cannot be sown or harvested, and nobody can move to another village or change their place of work.]. GUKP, 375 (31/36), pp. 170-1. 
the absence of any press reviews of the novel either in its first or second edition - a fact noted by Jerzy Smulski ${ }^{50}$ - suggests that the political authorities may have preferred to suppress public awareness of the novel and hence discussion of its potentially subversive nature.

The three novels by Andrzejewski, Stryjkowski and Cepik appeared in the more liberal publishing environment that developed from $1956 .{ }^{51}$ Although linked by the trope of the Inquisition, each novel provides a different narrative focus with implications for the novel's interpretations. Ciemności kryja ziemie (1957) foregrounds the relationship between the novice monk Diego and Torquemanda with the transformation of Diego's stance from one of opposition into the Grand Inquisitor's acolyte and successor. The novel functions as a master text in the Polish post-war context, providing a key point of reference for the two later novels discussed here. The cultural and political liberalization then dominating public life not only enabled the novel's publication but also a fuller critical discussion. ${ }^{52}$ Stylized sporadically as a medieval chronicle, its use of contemporary phraseology alerted readers to the relevance of the action for recent history.

Torquemada's call for vigilance from his subordinates, for instance, invokes a major propaganda slogan of the Stalin era: 'But we must be vigilant, brethren, we must not sleep while the enemy in our midst is awake. [Bądźmy jednak czujni i nie śpijmy wówczas, kiedy nie śpi nieprzyjaciel przebywający wśród nas]. ${ }^{93}$ The capacity of the inquisitorial system to explain the world contributes decisively to Diego's conversion to its cause: 'The lucid and universal character of the laws of Inquisition, which subordinated every detail to a monolithic, all-embracing concept, aroused respect and admiration in the young friar, but the consequences of these laws still troubled his conscience. [Przejrzystość oraz powszechny charakter tych praw, porządkujących szczegóły istnienia w jednolitą i wszystko wyjaśniającą całość, budziły w młodym braciszku podziw i szacunek, natomiast skutki ich oddziaływania wciąż się mu wydawały sprzeczne z odruchami jego sumienia.] ${ }^{54}$ The presentation of Diego's intellectual enslavement bears resemblance to certain

\footnotetext{
${ }^{50}$ J. Smulski, op. cit., p. 148. He also raises the question of its intended Aesopian character, qualifying it as a work that can be read rather as a 'political commentary', pp. 147-48.

${ }^{51}$ References to Ciemności are to the first edition (PIW, Warsaw 1957) with Konrad Syrop's English translation, entitled The Inquisitors (Weidenfeld and Nicolson, London 1960), being employed; for Przybysz, references are to the third edition (Wydawnictwo Literackie, Krakow 1993); Torquemada's first edition (Wydawnictwo Poznanskie, Poznan 1986) is used.

52 Testimony to the exceptional nature of the moment is the fact that the novel was not published again (and then for the last time in communist Poland) until 1973 when it appeared with two other works under the generic title of Three Novels (Trzy powieści).

${ }^{53}$ J. Andrzejewski, The Inquisitors, p. 14; idem, Ciemności..., p. 16.

${ }^{54}$ J. Andrzejewski, The Inquisitors, pp. 51-52; idem, Ciemności..., pp. 55-56.
} 
real-life admissions of intellectual submission to Stalinist ideology: ${ }^{55}$ the later oppositionist Jacek Kuron summed up the appeal of Marxist philosophy as lying precisely in its exposition of the world, its major failing being its inability to provide guidance on how to behave ethically.$^{56}$ Finally the concept of continual revolution, of Stalinist terror as a self-perpetuating system, informs Torquemada's definition of the rationale behind inquisitorial power to Diego:

One day if we run out of culprits, we shall have to create more. We need them so that crimes can be seen to be publicly humiliated and punished all the time. (...) Our power, my son, is based on universal fear. With the exception of a handful who are obedient from choice, everybody must be so afraid that no one is capable even of imagining an existence free of fear. ${ }^{57}$

[Gdyby pewnego dnia zabrakło winnych, musielibyśmy ich stworzyć, ponieważ są nam potrzebni, aby nieustannie, o każdej godzinie występek był publicznie poniżany i karany. (...) Konieczność naszej władzy, mój synu, od tego przede wszystkim zależy, aby strach, wyjąwszzy garstkę posłusznych z dobrej woli, stał się powszechnym, tak wypełniając wszystkie dziedziny życia, by nikt już sobie nie mógł wyobrazić istnienia bez lęku. $]^{58}$

The ritualistic and exemplary punishment of miscreants can be related as a general principle to the Stalinist showtrials of the early 1950s. Critics tended to take these analogies, and hence the overriding relevance of the novel to recent Polish history, for granted, ${ }^{59}$ articulating the parallels openly. Their occasional more or less transparent reference to Orwell's unconditionally banned 1984, implicitly assuming that readers would recognize their point, is extraordinary within post-war public discourse. ${ }^{60}$ This stemmed at least partly from the perceived

55 Diego's thinking echoes Czesław Miłosz's Zniewolony umyst (The Captive Mind, 1953), the classic account of this subjugation.

56 'It offered a young person the chance to order the world as he wanted. [...] what seemed to us gigantic progress, which we saw taking place before our very eyes, was at the same time creating a cultural desert. Now this new culture we were creating doesn't answer the question how you should live. It tells people how to act.' J. Rupnik, The Other Europe, Part 1. Channel 4. (1987).

57 J. Andrzejewski, The Inquisitors, p. 47.

${ }^{58}$ Idem, Ciemności..., p. 51.

${ }^{59}$ An anonymous comment stated that the novel employed 'historical costumes and decorations of the $15^{\text {th }}$ century'. Twórczość $1957,10-11$, p. 2. Stefan Durski even more curtly that 'the novel should be read from the contemporary perspective', Polityka, 10-17 June 1957, p. 7; Roman Zimand considered that 'we are dealing here with allusions, not with a direct accusation of Stalinism', Nowa Kultura, 25 August 1957, p. 6.

${ }^{60}$ Durski declared that the Inquisition acted like the Ministry of Truth in Orwell's 'well-known novel' (ibid.), while Henryk Bereza described Torquemada as both 'Caligula and [...] O'Brien', Nowa Kultura, 13 October 1957, pp. 8-9. 
inadequacy of the psychological characterization. ${ }^{61}$ Without entirely disputing these interpretations, others prioritized instead the novel's high literary genealogy (Dostoevskii and Romantic models) - the direct subordination of literature to political contingency presumably being uncomfortably close to practices under Socialist Realist doctrine. ${ }^{62}$ This degree of open discussion proved short-lived, however, as the party restored more stringent controls in the cultural sphere, ${ }^{63}$ although the novel itself remained part of the critical discourse.

In his review of Stryjkowski's novel, Tadeusz Nyczek establishes Ciemności from the outset as a key reference point, seeing Andrzewjewski's work as foregrounding 'the social and political mechanism which transforms a private way of viewing the world into the threat of fanatical collective rightness [mechanizm społeczno-polityczny przekształcający prywatne widzenie świata w groźbę fanatyzmu racji zbiorowych]', in contrast to the Romantic vision of resistance dealt with in Przybysz '[mamy do czynienia z romantyczną wizją oporu.]'64 The use of the abstruse 'social and political mechanism ...' indicates the scale of public retrenchment undertaken since the Thaw, when the socialist system ('Stalinism') could be named directly. Paradoxically, even the existence of an independent underground publishing network from 1976 (the 'second circulation [drugi obieg]') helped these circumlocutions to continue. Underground reviewers, like their public counterparts, often refrained from making explicit the subversive potential of works circulating above ground, deliberately casting their implications in the most general terms ${ }^{65}$ Nyczek's apparently throw-away comment regarding the novel's epigraph - 'It's no accident that the novel is dedicated to the Insurgents of the Warsaw Ghetto, and, perhaps, to all insurgents everywhere. [Nieprzypadkowo zadedykowana jest "Powstańcom Getta Warszawskiego". I bodaj wszystkim innym powstańcom.]' - is typical in its radical though obliquely phrased extension

${ }^{61}$ Bereza comments that most did not note in Diego 'the more or less profound disintegration of the human being [nie dostrzegano u niego mniej lub więcej głębokiej dezintegracji człowieka' (H. Bereza, op. cit., p. 8), thereby attributing a greater degree of credibility to his portrayal. The famous staging at Łódź's Teatr Nowy in 1957 was generally deemed to obviate this criticism.

62 R. Przybylski, Polityka, 30 October - 5 November 1957, p. 5; A. Kijowski, op. cit., p. 148. In critical discourse, this was usually phrased as the 'autonomous status [autonomiczność] of literature'.

${ }^{63}$ See the above-mentioned GUKP report of January 1969 (pp. 10-11). Tomasz Burek classed the novel as one of the forgotten works of the 'thaw' period in 'Zapomniana literatura polskiego Października”, in: idem, Żadnych marzeń, Polonia, London 1986. Andrzejewski’s own increasingly oppositionist stance and defiance of public norms (publishing in emigration under his own name, for instance) throughout the 1960s undoubtedly also played a major role in official caution towards his work.

64 T. Nyczek, Echo Krakowa, 29 May 1977, p. 4.

65 This type of restraint is also evinced by Loseff in The Beneficence of Censorship as well as the discussants in Farrell and Dewhirst's seminal The Soviet Censorship (1973), who largely limit their discussion to classic texts. 
of the novel's range of meanings ${ }^{66}$ Thus primed ${ }^{67}$ the readership would apply the novel's terms in the first instance to Polish society. ${ }^{68}$

The endangered community and the varied reactions of its inhabitants to the Inquisition's threat lend themselves to analogy with Polish experience on several levels. The very use of the trope of a besieged community (the barrio) arguably invokes this perception, with the declaration that 'we are a small nation [jesteśmy małym narodem] (132)' being one of those 'ungrammaticalities' that invariably prompted reflections on the Poles' own status.$^{69}$ In the absence of full statehood, Polish nineteenth-century discourse foregrounded national allegiance as the measure of identity; these terms tended to be updated to the current context as Janusz Tazbir's confiscated 1978 essay 'Dzieło literackie jako źródło współczesne [The Literary Work as a Contemporary Source]' articulates in exemplary fashion. Here the latter-day connotations of the pejorative 'małe państewko [little state]', applied to the post-Napoleonic solution of the Congress Kingdom of Poland, are teased out. ${ }^{70}$ Polish nineteenth-century experience offers then a critical perspective upon the post-war state and specifically social responses to oppression. The focus on Eli, the titular stranger who arrives in the barrio to organise communal resistance to the Inquisition, from this viewpoint invokes the Romantic insurrectionary option and links the barrio's discussions to opposition discourse on resistance within late 1970s Poland. ${ }^{71}$ Eli's exchange with Don Enrique about the Inquisition's modus operandi - its attempts to divide the community against itself - thus has more immediate relevance to late 1970s' than to previous contexts: 'The Inquisition instills fear, while the Inquisitor spreads slander via his spies. It's been a tried and tested weapon for centuries [Inkwizycja rzuca strach, a inkwizytor poprzez swoich szpiegów oszczerstwa. To wypróbowana broń. Od

${ }^{66}$ T. Nyczek, op. cit., p. 4.

${ }^{67}$ Irena Furnal's review is a masterpiece of insinuation, repeatedly directing the reader away from the literal level: 'Stryjkowski's word is burdened with an excess of meanings [...] it allows him to juggle freely with literary conventions, props, and to play a game with the reader.' Miesięcznik Literacki 1979, issue 1, pp. 128-130 (p. 130).

${ }^{68}$ Compare Stanisław Barańczak's review for the underground journal Zapis which concludes: 'Only one thing is certain [...]: whatever the outcome of this struggle between good and evil waged in the dark, taking part determines our humanity - it is our human duty.' Zapis 1979, issue 9, pp. $155-158$ (p. 158).

${ }^{69}$ A classic locus of the Poland-Israel analogy is the eighth sermon of the Jesuit polemicist Piotr Skarga's Kazania sejmowe (Sermons to the Sejm, 1597), later taken up and expanded by the Romantics in exile. See http://staropolska.pl/ang/renaissance/skarga.php3 (accessed on 11.10.2012).

${ }^{70}$ GUKP, 1342, Informacje miesieczne o dokonanych ingerencjach 1978 r. Informacja No. 7, p. 263.

${ }^{71}$ Helena Zatorska in her review entitled "Heroizm bez złudzeń [Heroism without Illusions]" notes 'The Stranger from Narbonne grew out of precisely this trend [of enthusiasm - JB] in Polish Romanticism which has lasted, as we know, deep into the twentieth century and is even more relevant today than it has ever been.' Twórczość 1978, issue 10, pp. 109-114 (p. 111). 
wieków]. ${ }^{72}$ The question of the best response to the Inquisition's onslaught oscillates between the options, which taxed Polish oppositionists, of Romantic revolt, or more precisely terrorist acts symbolized by the plot to assassinate the Inquisitor, and a gradualist political realism that threatened to blend into mere quietism. ${ }^{73}$ The rise of Solidarity, as Szaruga comments, resolved these dilemmas in a compromise unforeseeable during the late Gierek era. ${ }^{74}$

Critics played down the novel's status as mere 'costume drama', making a clear distinction from the treatment accorded to Andrzejewski's Ciemności. ${ }^{75}$ The greater degree of contextual detail and various screens employed in the novel and by reviewers shielded against straightforward identification of the community with Poland circa 1978 or the Inquisition with the Party. Stryjkowski's dedication rather deflected readers' attention to a (from the official perspective) less problematic parallel for the action - a rising against Nazi power (unlike the 1944 general uprising launched by non-communists) whose commemoration was state sanctioned. ${ }^{76}$ The Muslim presence in Spain, which has no clear counterpart within late 70s' Poland, and was therefore ignored by reviewers, in fact corresponds functionally to the Poles' status vis-a-vis the Jews during wartime, and may be viewed as reinforcing the dedication's misdirection. While the conventional Polish-Jewish parallel seemingly ascribes disproportionate threat to the 1970s' context, the common factor is a struggle phrased (in a perenially Polish manner) not so much in terms of politics as ethics, the defence of human dignity.

The focus upon the Grand Inquisitor in Cepik's Torquemada (1986) positions the novel in a direct relationship to Andrzejewski's Ciemności. Its comprehensive, factually-grounded account of the system Torquemada built prompted some of its mostly left-wing reviewers, however, to decry the earlier work's fictionality. ${ }^{77}$ Metaphorical readings of Cepik's novel tended to concentrate on parallels with the Nazis - the Inquisition's obsession with limpieza de sangre invoking their

72 J. Stryjkowski, Przybysz..., p. 216.

${ }^{73}$ Adam Michnik's foreword to Jacek Bocheński's book on 1970s' Italian terrorism highlights the terrorist option as topical within Polish underground discourse, Krwawe specjaty włoskie, Biblioteka Gazety Wyborczej, Warsaw 2009, pp. 11-12. See also L. Szaruga, Wobec totalitaryzmu. Kostium kościelny w polskiej prozie. Wobec cenzury, Ottonianum, Szczecin 1994, pp. 31-36.

74 Ibid., p. 35.

${ }^{75}$ See Szaruga's analysis of Jan Pieszczachowicz's review. Ibid., pp. 33-35. Barańczak comments 'obviously, the whole world of the novel can by no means be reduced to a historical costume. The proportion of specific, historical and cultural factors determining the characters' behaviour is too great.' S. Barańczak, op. cit., p. 158.

${ }^{76}$ Technically a screen according to Loseff's definition: On the Beneficence of Censorship. Aesopian Language in Modern Russian Literature, Verlag Otto Sagner, Munich 1984, pp. 50-52.

${ }^{77}$ Stanisław Zieliński's asserts that Cepik's portrayal of Torquemada's fascination with terror and power is more probable than Andrzejewski's doubt-ridden figure. Nowe Książki 1987, issue 2, pp. 69-71 (p. 69). 
racial policies ${ }^{78}$ - with the Soviet system being invoked solely in terms of the Stalinist cult. ${ }^{79}$ The latter assumption had considerable support in the novel, first in the possibility of equating Torquemada with Stalin: 'He treated doubt in his judgments and infallibility as doubt in the idea with which he identified. He was the idea. [Powątpienie w jego sądy i jego nieomylność traktował jako wątpienie $\mathrm{w}$ ideę. Utożsamiał się z nią. On był ideą]. ${ }^{90}$ References to future historical justification are redolent of the rationalization of monumental communist crimes: 'Great aims require superhuman sacrifices, whose value and necessity will be judged by the future. History will show we were right. [Wielkie cele wymagają nadludzkich ofiar, których wartość i potrzebę oceni przyszłość. - Historia przyzna nam rację.] $]^{\prime 81}$ The use of terror as the basic procedure for establishing social control, which Torquemada justifies to Queen Isabella, was common to secret police practices in both regimes, though the element of public punishment recalls Stalinist show trials: 'Naturally we will need stakes, but the essential punishment will be fear. I shall infect everyone with fear and then they will all obey you, my daughter. [Naturalnie stosy będą potrzebne. Ale karą istotną będzie strach. Porażę strachem wszystkich, a wtedy wszyscy będą Ci posłuszni, córko.] ${ }^{82}$

That there were only official press responses to Cepik's novel, and that these operate largely within the parameters established for Ciemności ${ }^{83}$ generates further reflections on the circumstances of its reception. A number of the reviews altogether eliminate any metaphorical dimension, emphasizing the novel's factual basis. By pointing up the continuation of the Inquisition into the nineteenth century and the Church's failure to denounce its activities, they return the Inquisition to the religious domain. ${ }^{84}$ From this perspective the absence of reviews from beyond the official spectrum may be read not merely as the trope's redundancy in a situation where a highly developed underground network enabled far more direct criticism of the political system. The absence of Catholic press reviews also may rather indicate that, in the highly polarized socio-political situation before glasnost', the novel was regarded as an official work that promoted the party's outlook.

${ }^{78}$ G. Kozera, "Wielki Inkwizytor”, Stowo Ludu, 22 May 1987, p. 5; K. Masłoń, Życie Warszawy, 27-28 July 1987, p. 5.

${ }^{79}$ Teresa Zaniewska refers to the 'personality cult' as one manifestation of later Inquisitions. Gazeta Wspótczesna, 10 July 1987, p. 6.

${ }^{80}$ J. Cepik, Torquemada, p. 170.

${ }^{81}$ Ibid., p. 225.

82 Ibid., p. 22.

${ }^{83}$ Zaniewska is an obvious exception, when her comparison of Cepik's work with Ciemności leads her to conclude that she would 'also grant a historiosophical dimension' to the former and asserts that 'the book will certainly remain relevant to the present situation.' T. Zaniewska, op. cit., p. 5.

${ }^{84}$ Respectively, S. Zieliński, op. cit., p. 70, and W. Jamrozik, "Opowieść o Wielkim Inkwizytorze", Głos Wielkopolski, 25-26 April 1987, p. 5. 
The power of the Church caused the party concern throughout the whole post-war period; by the 1980s these anxieties centred on the potent combination of Romantic-inflected public defiance and religious fundamentalism. Tadeusz Drewnowski, a party member enjoying broad political respect, obliquely (though transparently) raised this eventuality in his speech at the XXI Writers' Congress in December 1980, when he said, 'By exploiting national complexes and frustrations, not to mention the authorities' ineptitude, it [a significant part of the opposition] escalates the social mood as if we were heading into a new Warsaw Uprising or the return of Chomeini. [Wykorzystując kompleksy i frustracje narodowe, nie wspominając o niezręcznościach władzy, eskaluje ona nastroje, niczym przed nowym Powstaniem Warszawskim, czy przed powrotem Chomeiniego.] ${ }^{85}$ The resuscitation of Romantic behavioural models allied to a reflexive Catholicism, ${ }^{86}$ which appeared to threaten the state authorities with total exclusion from any role in social dialogue, proved to be a constant refrain in contemporary official discourse. ${ }^{87}$

Ironically, then, by the mid-1980s, it was precisely the party that feared being silenced. Silencing dissent from and resistance to the official version had been equally intrinsic to both its and the Inquisition's operations. In Andrzejewski's and Cepik's narratives, the Inquisition achieves the psychological and moral disintegration of its victims precisely through silencing. The protocol of Lorenzo Perez's interrogation in Ciemności illustrates the success of inquisitorial methods: ${ }^{88}$ his initial resistance, marked by the repeated recording of his silence ('milczal [does not reply]') in response to Torquemada's questions and assertions gives way on the second day to a ready acceptance of the Grand Inquisitor's version, which is underlined by his denunciation of 'several score' of fellow-conspirators. ${ }^{89} \mathrm{In}$ Torquemada the release of torture victims in 1492 is described as embodying the principle of silence imposed by the Inquisition both on the victims themselves and potential rebels: 'They were a mute warning to the rebellious [...] mute because those cripples were not allowed to tell what they had endured during torture, and would not confide even to their closest family out of fear that they would again find themselves in prison. [Były to nieme ostrzeżenia dla niepokornych [...] nieme, bo owym kalekim nie wolno było mówić, co przeżyli na torturach, nie zwierzali się $\mathrm{z}$ tego nawet najbliższym w trwodze, że znowu znajdą się w wiezięniach.] ${ }^{90}$

\footnotetext{
${ }^{85}$ XXI Walny Zjazd ZLP 28-29 XII 1980. 11.723. Tom I: 28 grudnia 1980, p. 164.

${ }^{86}$ As one colleague - then a student - put it, 'we would leave the Church and join a demo against the regime.' This practice was purely tactical.

${ }^{87}$ Jerzy Ładyka's article "Literatura i polityka" in the Party's theoretical monthly provides an exemplary exposition of these anxieties, Nowe Drogi 1985, issue 7, pp. 154-162.

${ }^{88} \mathrm{~J}$. Andrzejewski, Ciemności..., pp. 118-134; idem, The Inquisitors, pp. 108-123.

${ }^{89}$ J. Andrzejewski, Ciemności..., p. 132; idem, The Inquisitors, p. 122.

90 J. Cepik, Torquemada, pp. 278-279.
} 
By contrast, Stryjkowski's narrative emphasizes resistance to the Inquisition's discourse.$^{91}$ Miguel Taronga, who refuses to implicate others, even when faced by his own imminent execution at the stake, presents the most acute example. His final exchange with the Inquisitor demonstrates his principled denial of the Inquisition's version. ${ }^{92}$ In contrast to the other novels, human solidarity remains possible. Eli's cry of support to Miguel in his final agony represents an act of both humanity and defiance against the Inquisition's power: 'Eli was convulsed by a mute sob. "Miguel, peace be with you, Jew!" he shouted with all his might. Miguel opened his eyes, raised them to the heavens whence the voice came. God himself desired to bring him relief. [Elim wstrząsną głuchy szloch. 'Miguel, pokój z tobą, Żydzie!' krzyknął ze wszystkich sił. / Miguel otworzył oczy. Podniósł je do nieba. Stamtąd przyszedł głos. Bóg sam chciał mu ulżyć.] ${ }^{93}$ The breaking of silence here by Eli and, following his arrest for this act, in his later dispute with the Inquisitor San Martin in prison, enables the articulation of the significance of the Jews' silence: 'But in your disputation it is not rightness that prevails but might. That's how it was at Tortosa. Force took precedence over proof. Each proof was destroyed as if it were blasphemy. A person whose life is in danger has sealed lips. A dispute can take place only between equals... [Ale w waszej dyspucie wygrywa nie słuszność, ale siła. Tak było w Tortosie. Nad dowodami panowała przemoc. Każdy dowód był niszczony jako bluźnierstwo. Zagrożony ma zamknięte usta. Dysputa może być tylko między równymi.] ${ }^{94}$ Initially, Eli insists merely upon the illegality of his arrest, as a foreign Jew not subject to Spanish Church law. His refusal to respond therefore reflects Brown's assertion that 'silence $[\ldots]$ can also function as resistance to regulatory discourse. ${ }^{95}$ In replying to San Martin he seeks to subvert the automatic assumption of the Inquisitional discourse's power. In both instances his defiance seems to mark that 'shocking outspokenness', to which - as Bourdieu asserts - structural censorship condemns the 'occupants of dominated positions. ${ }^{96}$ Eli is not, of course, compelled to accept the subordinate status of one whose silence can be construed as

${ }^{91}$ Stryjkowski's research in Spanish archives was funded by the Franco regime. He noted in conversation with Piotr Szewc that the protocols of the interrogations he found in the cathedral in Las Palmas were almost identical in terms of the questions and responses. The fact that nobody confessed their guilt, despite facing certain execution, seems pertinent to Przybysz's narrative. P. Szewc, Ocalony na wschodzie. Z Julianem Stryjkowski rozmawia Piotr Szewc, Les Editions Noir sur Blanc, Montricher, Suisse 1991, p. 270.

92 J. Stryjkowski, Przybysz..., p. 110.

${ }^{93}$ Ibid., p. 119.

${ }^{94}$ Ibid., p. 129.

95 W. Brown, op. cit., p. 318.

${ }^{96}$ P. Bourdieu, "Censorship and the Imposition of Form", in: Language and Symbolic Power, ed. and introduced J.B. Thompson; trans. G. Raymond and M. Adamson, Polity Press, Cambridge 2003, p. 138. 
resistance: he has the option to leave. ${ }^{97}$ For the Jews in the barrio, determined to remain, such silence is compromised, being merely (as Brown attests) 'a defense in the context of domination, a strategy for negotiating domination, rather than a sign of emancipation from it. ${ }^{98}$

In all three cases, silence is inscribed into the text. Its integral nature suggests a comparable significance to the principle of historically contingent screen and marker that typify Aesopian works. These texts and their characters perform silence. Within a logocracy this performance may hold incalculable value since, in accordance with Macherey's dictum, 'speech eventually has nothing more to tell us: we investigate the silence, for it is the silence that is doing the speaking. ${ }^{99}$

\section{Bibliography}

Andrzejewski Jerzy, Ciemności kryją ziemię, PIW, Warsaw 1957.

Andrzejewski Jerzy, The Inquisitors, trans. Konrad Syrop, Weidenfeld and Nicolson, London 1960.

Augustine, On Baptism, 7 39:77, PL, 43, col. 257.

Bates John, "Cenzura wobec problemu niemieckiego w literaturze”, in: Presja i ekspresja: Zjazd Szczecinski i Socrealizm, Danuta Dąbrowska and Piotr Michałowski (eds), Wydawnictwo Naukowe Uniwersytetu Szczecinskiego, Szczecin 2002, pp. 79-92.

Blyum Arlen, A Self-Administered Poison: The System and Functions of Soviet Censorship, trans.

I.P. Foote, University Humanities Research Centre, University of Oxford: Legenda Special Lecture Series 5, 2003.

Bocheński Jacek, Krwawe specjały włoskie, Biblioteka Gazety Wyborczej, Warsaw 2009.

Bourdieu Pierre, "Censorship and the Imposition of Form", in Language and Symbolic Power, ed. John B. Thompson; trans. Gino Raymond and Matthew Adamson, Polity, Cambridge 2003, pp. 137-159.

Brown Wendy, "Freedom's Silences", in: Censorship and Silencing: Practices of Cultural Regulation, Robert C. Post (ed.), The Getty Institute for the History of Art and the Humanities, Los Angeles 1998, pp. 313-327.

Budrowska Kamila, Literatura i pisarze wobec cenzury PRL 1948-1958, Wydawnictwo Uniwersytetu w Białymstoku, Białystok 2009.

Burek Tomasz, “Zapomniana literatura polskiego Października”, in: idem, Żadnych marzeń, Polonia, London 1986, pp. 53-73.

Cepik Jozef, Torquemada, Wydawnictwo Poznańskie, Poznan 1986.

${ }^{97}$ Functionally, to resituate the novel in the context of 1970s' Poland opposition, Eli's gestures mirror some parts of the opposition movement who sought to act as though they lived in a free/ normal society. See, for instance, the practice of publishing the real names and addresses of editors and writers associated with the underground journal Zapis, which amounted to a declaration of the legality of their activity.

${ }^{98}$ W. Brown, op. cit., p. 324.

99 P. Macherey, A Theory of Literary Production, trans. G. Wall, Routledge, London and New York 2006, p. 96. 
Goldstein Robert Justin, “Aesopian Writing”, in: Censorship: A World Encyclopedia, Derek Jones (ed.), Fitzroy Dearborn, London-Chicago 2001, pp. 16-17.

Groot Jerome de, The Historical Novel, Routledge, London and New York 2010.

Herbert Zbigniew, "Obrona Templariuszy" [Defence of the Templars], in: idem, Barbarzyńca w ogrodzie, Czytelnik, Warsaw 1964.

Kołakowski Leszek, Towards a Marxist Humanism: Essays on the Left Today, trans. Jane Zielonko Peel, Grove, New York 1968, pp. 9-37.

Kras Paweł, Husyci w piętnastowiecznej Polsce, Towarzystwo Naukowe KUL, Lublin 1998.

Loseff Lev, On the Beneficence of Censorship. Aesopian Language in Modern Russian Literature, Verlag Otto Sagner, Munich 1984.

Ładyka Jerzy, "Literatura i polityka", Nowe Drogi 1985, issue 7, pp. 154-162.

Macherey Pierre, A Theory of Literary Production, trans. Geoffrey Wall, Routledge, London-New York 2006.

Mezinárodni ohlas Husitství, Josef Maček (ed.), Nakl. Československé akademie věd, Prague 1958.

Misior Paweł, Ja, Tomasz Strzyżewski. O cenzurze i cenzorach, Léon Bonnet, Cracow 1997.

Patterson Annabel, Censorship and Interpretation: The Conditions of Writing and Reading in Early Modern England, University of Wisconsin Press, Madison, Wisconsin 1991 [original edn 1984].

Reifarth Gert, Philip Morrissey, "Aesopic Voices: A Foreword”, in: Aesopic Voices. Reframing Truth through Concealed Ways of Presentation in the $20^{\text {th }}$ and $21^{\text {st }}$ Centuries, Reifarth and Morrissey (ed.), Cambridge Scholars Publishing, Newcastle upon Tyne 2011, pp. 1-12 (p. 3); http://www.c-s-p.org/flyers/978-1-4438-3443-8-sample.pdf (accessed on 15.10.2012).

Riffaterre Michael, Semiotics of Poetry, Methuen, London 1978.

Romek Zbigniew, Cenzura a nauka historyczna w Polsce 1944-1970, Wydawnictwo Neriton, Warsaw 2010.

Rupnik Jacques, The Other Europe. Part 1. Channel 4. 1987.

Schreiber Jürgen, Jerzy Andrzejewskis Roman 'Ciemości kryją ziemię’ und die Darstellung der spanischen Inquisition in Werken der fiktionalem Literatur, Otto Sagner, München 1981.

Skarga Piotr, Kazania sejmowe (Sermons to the Sejm, 1597); http://staropolska.pl/ang/renaissance/ skarga.php3 (accessed on 11.10.2012).

Smulski Jerzy, "Jak niewyrażalne staje się wyrażalne? O języku ezopowym w prozie polskiej lat pięćdziesiątych", in: Literatura wobec niewyrażalnego, Włodzimierz Bolecki and Erazm Kuźma (eds.), PAN, Warsaw 1998, pp. 145-164.

Stryjkowski Julian, Przybysz z Narbony, Wydawnictwo Literackie, Krakow 1993 [original ed. 1978].

Sulikowski Bogusław, “Ten przeklety jezyk ezopowy ...”, in: Piśmiennictwo - systemy kontroli - obiegi alternatywne, tom II, J. Kostecki and A. Brodzka (eds.), Biblioteka Narodowa, Warsaw 1992, pp. 265-284.

Szaruga Leszek, Wobec totalitaryzmu. Kostium kościelny w polskiej prozie. Wobec cenzury, Ottonianum, Szczecin 1994.

Szewc Piotr, Ocalony na wschodzie. Z Julianem Stryjkowski rozmawia Piotr Szewc, Noir sur Blanc, Montricher, Switzerland 1991.

“Zabijanie słowa: O cenzurze w PRL”, Biuletyn Instytutu Pamięci Narodowej 2004, issue 2, pp. 4-26. 
John Bates

\title{
Parables of Un-freedom: Novels about the Spanish Inquisition in post-1956 People's Poland ${ }^{100}$
}

\author{
(Summary)
}

The article examines three post-1956 novels ostensibly about the Spanish Inquisition's activities in Spain at the end of the fifteenth century: Jerzy Andrzejewski's Ciemności kryja ziemię (The Inquisitors, 1957), Julian Stryjkowski's Przybysz z Narbony (1978), and Jozef Cepik's Torquemada (1986). These works are placed in a number of broader contexts: the uses of the historical novel in Poland; post-war Polish censorship discourse about the use of historical analogy to address current social and political problems, a practice which the political authorities sought to restrict; the contemporary critical reception where reviews of each novel are seen as articulating the novels' fundamental concerns albeit subject to the same censorship restrictions; and ultimately the longestablished tradition of Aesopian writing within Polish literature. The analysis demonstrates the expansion of the space for critical public expression particularly in the Thaw years of 1956-57, and its contraction over time up to the mid-1970s. The rise of an independent publishing network at that point paradoxically both facilitates a more open discussion of the potential meanings of literary texts but equally has to observe censorship proprieties to avoid exposing officially published authors to political sanctions. With the growth of underground publishing, the Spanish Inquisition theme gradually declines in relevance, reflected by the critical marginalisation of Cepik's novel. Ultimately, the article positions the trend within Macherey's theory of significant silences within literary works, which permits a refinement of the historically contingent screen and marker that have typically defined Aesopian works. The article presents, with their English translations, hitherto unpublished documents from the Polish Party and Censorship archives, including examples of work confiscated by the censors.

Keywords: Censorship, Inquisition, Poland, medieval, Spain, control, silence, the Thaw, independent publishing, underground, historical novel, Polish literature, Aesopian

${ }^{100}$ This publication is one of the outcomes of the research project "Examining Patterns of Representation in Literary Discourses" (OPVK CZ.1.07/2.3.00/20.0125), which has been jointly financed by the European Social Fund and the State Budget of the Czech Republic. 